\title{
PERBANDINGAN KEMAMPUAN PEMECAHANMASALAH MATEMATIS SISWA MENGGUNAKAN MODEL ELICITING ACTIVITIES DAN PROBLEM BASED LEARNING DI KELAS VIII SMP NEGERI 38 MEDAN
}

\author{
Novia Fadilah ${ }^{1}$, Edy Surya ${ }^{2}$ \\ ${ }^{1,2)}$ FMIPA, Universitas Negeri Medan, Sumatera Utara, Indonesia \\ fadilahnovia@gmail.com
}

\begin{abstract}
ABSTRAK
Penelitian ini bertujuan untuk mengetahui apakah kemampuan pemecahan masalah matematis siswa yang belajar dengan menggunakan model pembelajaran MEAs lebih tinggi daripada kemampuan pemecahan masalah matematis siswa yang belajar dengan menggunakan model pembelajaran PBL di SMP Negeri 38 Medan. Jenis penelitian ini adalah penelitian eksperimen. Populasi dalam penelitian ini adalah seluruh siswa kelas VIII SMP Negeri 38 Medan semester genap, yang terdiri dari 5 kelas. Sampel dalam penelitian ini adalah dua kelas yang dipilih berdasarkan kelas-kelas atau kelompok yang sudah ada, dimana kelas VIII-4 sebagai kelas eksperimen MEAs dengan jumlah sampel 38 orang dan kelas VIII-5 sebagai kelas eksperimen PBL dengan jumlah sampel 39 orang. Penelitian ini menggunakan dua jenis instrument yaitu pre-test dan post-test dalam bentuk uraian. Dari hasil penelitian yang diberikan, diperoleh nilai rata-rata posttest kelas eksperimen MEAS 79,6842 dan kelas eksperimen PBL memperoleh nilai rata-rata 71,9487. Dari hasil uji hipotesis post-test diperoleh $t_{\text {hitung }}(1,9044)>t_{\text {tabel }}$ (1,6675) dengan demikian diperoleh kesimpulan bahwa kemampuan pemecahan masalah matematis siswa yang belajar dengan menggunakan model pembelajaran MEAs lebih tinggi daripada kemampuan pemecahan masalah matematis siswa yang belajar dengan menggunakan model pembelajaran PBL di SMP Negeri 38 Medan T.A $2016 / 2017$
\end{abstract}

Kata kunci: Pemecahan Masalah Matematis, MEAs, PBL

\begin{abstract}
This research aims to find out whether a mathematical problem solving abilities students learning by using learning model MEAs is higher than the ability of mathematical problem solving of students who learn by using the learning model PBL in SMP Negeri 38 Medan. This type of research is research experiments. The population in this research is the whole grade VIII SMP Negeri Medan 38 semester even, consisting of 5 classes. The sample in this study were selected based on two classes of classes or groups that already exist, where the class VIII-4 experimental MEAs as a class with the number of samples of 38 people and class VIII-experimental class 5 as PBL with a number of samples of 39
\end{abstract}

Novia Fadilah, Edy Surya. Perbandingan Kemampuan Pemecahan Masalah Matematis Siswa Menggunakan Model Eliciting Activities dan Problem Based Learning di Kelas VIII SMP Negeri 38 Medan, Inspiratif, Vol. 3, No. 1 April 2017. 
people. This study uses two types of instrument, namely pre-test and post-test in the form of descriptions. Of research results are given, obtained average value of experimental class posttest MEAS 79,6842 experimental class and PBL gained an average rating of 71,9487. Hypothesis test results from post-test is obtained (1.9044) > (1.6675) thus obtained conclusions that the ability of mathematical problem solving of students learning by using learning model of the MEAs is higher than the ability of mathematical problem solving of students who learn by using the learning model PBL in SMP Negeri 38 Medan 2016/2017.

\section{Keywords: Mathematical problem solving, MEAs, PBL}

\section{PENDAHULUAN}

Pendidikan merupakan hal yang sangat penting bagi manusia, karena pendidikan merupakan investasi sumber daya manusia dalam jangka panjang. Dengan demikian, pendidikan selalu menuntut adanya suatu perubahan dan perbaikan secara terus menerus. Tuntutan mendasar yang dialami dunia pendidikan saat ini adalah peningkatan mutu pelajaran. Upaya untuk meningkatkan mutu pendidikan diharapkan dilakukan pada setiap mata pelajaran khususnya mata pelajaran matematika.

Di Uni Eropa, matematika dianggap sebagai kunci pembangunan suatu negara (Santillán, dkk, 2016:361). Matematika juga merupakan mata pelajaran yang paling penting dalam kurikulum di seluruh dunia karena matematika memiliki hubungan langsung dengan mata pelajaran lain (Sa'ad, dkk, 2014:32). Selain itu Byod, dkk (2014:207-208) menyatakan bahwa: Memahami matematika diakui sebagai hal penting dalam kehidupan sehari-hari dan matematika merupakan bagian dari pekerjaan professional seperti tehnik, kedokteran, ilmu pengetahuan dan pendidikan. Sehingga guru diharapkan kompeten akan keterampilan matematika mereka, memiliki pemahaman yang mendalam dan mampu mengajar secara efektif sehingga siswa berhasil dalam pembelajaran matematika.

Afgani (dalam Mawaddah dan Aisyah, 2015:166) berpendapat bahwa:
"Kebermaknaan dalam belajar matematika akan muncul manakala aktivitas yang dikembangkan dalam belajar matematika memuat standar proses pembelajaran matematika, yakni pemahaman, penalaran, komunikasi, koneksi, pemecahan masalah, dan representasi". Sedangkan menurut Permendiknas dalam Delyana (2015:26) menyatakan bahwa: "Salah satu tujuan pembelajaran matematika di sekolah adalah memecahkan masalah masalah yang meliputi kemampuan memahami masalah, merancang model matematika, menyelesaikan model dan menafsirkan solusi yang diperoleh". Dengan perkataan lain, bila peserta didik dilatih menyelesaikan masalah, maka peserta didik itu akan mampu mengambil keputusan, sebab peserta didik itu telah menjadi terampil tentang bagaimana mengumpulkan informasi yang relevan, menganalisis informasi, dan menyadari betapa perlunya meneliti kembali hasil yang telah diperolehnya (Hudojo, 2005: 130). Siswa juga harus memiliki kemampuan pemecahan masalah matematis (Surya, 2013).

NCTM mengungkapkan bahwa, solving problems is not only a goal of learning mathematics but also a major means of doing so. ... In everyday life and in the workplace, being a good problem solver can lead to great advantages. ... Problem solving is an integral part of all mathematics learning. Maknanya, memecahkan masalah bukan hanya tujuan dari pembelajaran matematika tetapi juga

Novia Fadilah, Edy Surya. Perbandingan Kemampuan Pemecahan Masalah Matematis Siswa Menggunakan Model Eliciting Activities dan Problem Based Learning di Kelas VIII SMP Negeri 38 Medan, Inspiratif, Vol. 3, No. 1 April 2017. 
sarana utama untuk melakukannya, dalam kehidupan sehari-hari dan di tempat kerja, menjadi seorang pemecah masalah yang baik dapat memberikan keuntungan yang besar, pemecahan masalah juga merupakan bagian dari semua pembelajaran matematika (Pehkonen, 2007 :1).

Dari uraian di atas dapat disimpulkan bahwa kemampuan pemecahan masalah merupakan kemampuan yang sangat penting dalam pembelajaran matematika dan merupakan salah satu dari kompetensi yang harus dimiliki oleh peserta didik karena pemecahan masalah matematis merupakan salah satu standar yang sangat dibutuhkan dalam pembelajaran matematika dan menjadi salah satu tujuan dari pembelajaran matematika.. Berbicara mengenai pemecahan masalah matematika tidak dapat terlepas dari tokoh utamanya, yakni George Polya. Menurut Polya terdapat empat tahapan penting yang harus ditempuh siswa dalam memecahkan masalah, yakni memahami masalah, menyusun rencana penyelesaian, melaksanakan rencana penyelesaian, dan memeriksa kembali. Melalui tahapan yang terorganisir tersebut, siswa akan memperoleh hasil dan manfaat yang optimal dari pemecahan masalah (Hartono,2013:3). Selain itu Menurut Bransford dan Stein manyatakan bahwa langkah-langkah dalam menemukan pemecahan masalah yang efektif adalah sebagai berikut :

1. Temukan dan susun masalahnya.

2. Kembangkan strategi pemecahan masalah yang baik. Beberapa strategi yang efektif adalah menentukan subtujuan (subgoaling), dan algoritma.

3. Analisis terhadap hasil akhir (means and analysis).

4. Mengevaluasi hasil-hasil (Noor dan Nurlaila, 2014:253).

Berdasarkan uraian tersebut yang dimaksud kemampuan pemecahan masalah matematika dalam penelitian ini mencakup beberapa langkah yaitu :

1. Memahami masalah yaitu menentukan hal yang diketahui dalam soal dan menentukan hal yang ditanyakan.

2. Merancang model matematika. Setelah masalah telah dipahami, langkah selanjutnya adalah merancang atau merencanakan model matematika dengan menerjemahkan suatu masalah kedalam bahasa matematika baik menggunakan persamaan, pertidaksamaan, atau fungsi.

3. Menjalankan rancangan model yaitu melaksanakan rancangan atau rencana yang telah dibuat pada langkah kedua.

4. Menafsirkan hasil yang diperoleh dengan membuat kesimpulan terhadap jawaban atas permasalahan (Noor dan Nurlaila, 2014:254).

Mengingat pentingnya kemampuan pemecahan masalah matematis siswa terhadap pembelajaran matematika, guru diharapkan memilih model pembelajaran yang sesuai dengan materi yang diajarkan agar siswa lebih tertarik dan termotivasi untuk mengikuti pembelajaran yang dilaksanakan oleh guru. Pembelajaran yang dapat memaksimalkan pemikiran siswa dapat membangun karakter bangsa. Kemampuan pemecahan masalah matematis adalah jantung matematika (Surya, 2010). Trianto (2011:26) menyatakan bahwa: "Dalam mengajarkan suatu pokok bahasan (materi) tertentu harus dipilih model pembelajaran yang sesuai dengan tujuan yang akan dicapai". Alternatif model pembelajaran yang diduga sesuai untuk memfasilitasi kemampuan pemecahan masalah matematis siswa adalah model pembelajaran Model Eliciting Activities (MEAs) dan model pembelajaran Problem Based Learning (PBL). MEAs dan PBL merupakan model pembelajaran yang 
sama-sama bertujuan untuk meningkatkan daya tarik siswa dalam memecahkan masalah.

Model Eliciting Activities (MEAs) merupakan model pembelajaran yang memfokuskan aktivitas siswa untuk mendapatkan atau memperoleh penyelesaian dari masalah yang diberikan melalui proses mengaplikasikan prosedur matematis untuk membentuk sebuah model matematika (Chamberlin dan Moon, 2008:4). Tujuan utama dari pembelajaran ini adalah siswa dapat mengaplikasikan prosedur matematis untuk membentuk sebuah model matematika. Dengan pembelajaran Model Eliciting Activities (MEAs), belajar siswa lebih bermakna karena ia dapat menghubungkan yang dipelajarinya dengan konsep yang sudah diketahuinya. Pembelajaran MEAs merupakan jembatan antara model dan interprestasi, memberikan peluang besar kepada siswa untuk mengeksploitasi pengetahuannya dalam belajar matematika (Permana, 2010). Jadi, siswa diharapkan tidak hanya sekedar menghasilkan model matematika tetapi juga mengerti konsepkonsep yang digunakan dalam pembuatan model matematika dari permasalahan yang diberikan

Chamberlin menyatakan bahwa Model Eliciting Activities diterapkan dalam beberapa langkah, yaitu:

1) Pendidik membaca sebuah lembar permasalahan yang mengembangkan konteks peserta didik

2) Peserta didik siap siaga terhadap pertanyaan berdasarkan lembar permasalahan tersebut

3) Pendidik membacakan permasalahan bersama peserta didik dan memastikan bahwa setiap kelompok mengerti apa yang sedang ditanyakan

4) Peserta didik berusaha untuk menyelesaikan masalah tersebut

5) Peserta didik mempresentasikan model matematika mereka setelah membahas dan meninjau ulang solusi (Chamberlin dan Moon, 2008:5)
Berdasarkan uraian di atas, MEAs adalah model pembelajaran yang mendukung aktifitas siswa dalam mendatangkan, mendapatkan atau memperoleh solusi dari masalah yang diberikan melalui proses berfikir siswa untuk menciptakan sebuah model matematika sebagai solusinya. Selain itu, MEAs didasarkan pada situasi kehidupan nyata siswa, bekerja dalam kelompok kecil, dan menyajikan sebuah model matematis sebagai solusi, serta menginterpretasikan solusi pemecahan masalah tersebut kembali ke dunia nyata.

Sedangkan, model pembelajaran Problem Based Learning (PBL) atau pembelajaran berbasis masalah adalah suatu model pembelajaran yang melibatkan siswa untuk memecahkan suatu masalah melalui tahap-tahap metode ilmiah sehingga siswa dapat mempelajari pengetahuan yang berhubungan dengan masalah tersebut sekaligus memiliki keterampilan untuk memecahkan masalah. Menurut Sanjaya (2011:215) menyatakan bahwa:

PBL diartikan sebagai rangkaian aktivitas yang menekankan kepada proses penyelesaian masalah yang dilakukan secara ilmiah. Terdapat 3 ciri utama dalam PBL. Pertama, PBL merupakan rangkaian aktivitas pembelajaran artinya dalam implementasi PBL peserta didik tidak hanya sekadar mendengarkan, mencatat, kemudian menghafal materi pelajaran, akan tetapi melalui PBL peserta didik aktif berpikir, berkomunikasi, mencari dan mengolah dan akhirnya menyimpulkan. Kedua, aktivitas pembelajaran diarahkan untuk menyelesaiakn masalah. Ketiga, pemecahan masalah dilakukan dengan menggunakan pendekatan berpikir secara ilmiah.

Adapun langkah-langkah Problem Based Learning (PBL) (Trianto 2011:98) dalam pembelajaran adalah sebagai berikut:

1. Mengorientasi siswa pada masalah 
2. Mengorganisasikan siswa untuk belajar

3. Membimbing penyelidikan individual maupun kelompok,

4. Mengembangkan menyajikan hasil karya,

5. Menganalisis dan mengevaluasi proses pemecahan masalah.

Dengan karakteristik dari dua model pembelajaran tersebut, pembelajaran yang berlangsung akan membangkitkan ketertarikan siswa dalam memecahkan masalah matematika, membuat siswa lebih aktif dan bersosialisasi, serta mendorong kerjasama antar siswa dalam mempelajari suatu materi. Dan karena ditemukannya beberapa penelitian yang relevan mengenai peningkatan kemampuan pemecahan masalah dari model pembelajaran tersebut.

\section{METODE}

Penelitian yang digunakan adalah kuasi eksperimen. Desain penelitiaannya adalah two group pretest and posttest design.

Tabel 1. Desain Penelitian

\begin{tabular}{|c|c|c|}
\hline $\begin{array}{c}\text { Pengukuran } \\
\text { Pretest }\end{array}$ & Perlakuan & $\begin{array}{c}\text { Pengukuran } \\
\text { Posttest }\end{array}$ \\
\hline $\mathrm{TA}_{1}$ & $\mathrm{X}_{1}$ & $\mathrm{~TB}_{1}$ \\
\hline $\mathrm{TA}_{2}$ & $\mathrm{X}_{2}$ & $\mathrm{~TB}_{2}$ \\
\hline
\end{tabular}

Keterangan :

(Sugiono, 2016:112)

$\mathrm{X}_{1}$ : Perlakuan yang akan diberikan pada kelas eksperimen 1 dengan model pembelajaran Model Eliciting Activities (MEAs)

$\mathrm{X}_{2}$ : Perlakuan yang akan diberikan pada kelas eksperimen 2 dengan model pembelajaran Problem Based Learning (PBL)

$\mathrm{TA}_{1}$ : Tes awal (pretest) yang diberikan pada kelas eksperimen 1
$\mathrm{TA}_{2}$ : Tes awal (pretest) yang diberikan pada kelas eksperimen 2

$\mathrm{TB}_{1}$ : Tes akhir (posttest) yang diberikan pada kelas eksperimen 1

$\mathrm{TB}_{2}$ : Tes akhir (posttest) yang diberikan pada kelas eksperimen 2

\section{HASIL DAN PEMBAHASAN}

Dalam penelitian ini data yang akan diolah adalah nilai pretest dan posttest siswa.

\section{Tabel 2. Data Nilai Pretest Kelas} Eksperimen MEAs dan PBL

\begin{tabular}{|c|c|c|}
\cline { 2 - 3 } \multicolumn{1}{c|}{} & MEAs & PBL \\
\hline Jumlah & 1850 & 1580 \\
\hline Rata-rata & 48,6842 & 40,5128 \\
\hline Varians & 382,9787 & 287,3090 \\
\hline $\begin{array}{c}\text { Simpangan } \\
\text { Baku }\end{array}$ & 19,5698 & 16,9502 \\
\hline Maksimum & 82 & 80 \\
\hline Minimum & 10 & 10 \\
\hline
\end{tabular}

Berdasarkan tabel di atas terlihat bahwa jumlah nilai kelas eksperimen I 1850 dengan rata-rata 48,6842 dan simpangan baku 19,5968 sedangkan kelas eksperimen II 1580 dengan rata-rata 40,5128 dan simpangan baku 16,9502. Data ini selanjutnya akan dianalisis untuk menerima atau menolak hipotesis penelitian.

\section{Uji Normalitas Data}

Salah satu persyaratan analisis yang harus dipenuhi agar dapat menggunakan statistik parametrik uji-t adalah sebaran data harus berdistribusi normal. Untuk menguji normal tidaknya data dilakukan dengan menggunakan uji Lilifors, dengan syarat normal jika $\mathrm{L}_{\text {hitung }}<\mathrm{L}_{\text {tabel }}$ pada taraf $\alpha=0,05$. Secara ringkas hasil perhitungan data-data hasil penelitian diperlihatkan pada tabel-tabel berikut:

Novia Fadilah, Edy Surya. Perbandingan Kemampuan Pemecahan Masalah Matematis Siswa Menggunakan Model Eliciting Activities dan Problem Based Learning di Kelas VIII SMP Negeri 38 Medan, Inspiratif, Vol. 3, No. 1 April 2017. 
Tabel 3. Data Hasil Uji Normalitas Data Pretest

\begin{tabular}{|c|c|c|c|}
\hline \multirow{2}{*}{ Kelas } & \multicolumn{3}{|c|}{ Pre Test } \\
\cline { 2 - 4 } & $\mathbf{L}_{\text {hitung }}$ & $\mathbf{L}_{\text {tabel }}$ & Ket \\
\hline Eks 1 & 0,0948 & 0,1437 & Normal \\
\hline Eks 2 & 0,0924 & 0,1419 & Normal \\
\hline
\end{tabular}

Dari tabel tersebut dapat disimpulkan bahwa data pretest pada kedua kelompok sampel berdistribusi normal.

Tabel 4. Data Hasil Uji Normalitas Data Postest

\begin{tabular}{|l|c|c|c|}
\hline \multirow{2}{*}{ Kelas } & \multicolumn{3}{|c|}{ Post Test } \\
\cline { 2 - 4 } & $\mathbf{L}_{\text {hitung }}$ & $\mathbf{L}_{\text {tabel }}$ & Ket \\
\hline Eks 1 & 0.1131 & 0,1437 & Normal \\
\hline Eks 2 & 0,0947 & 0,1419 & Normal \\
\hline
\end{tabular}

Dari tabel tersebut dapat disimpulkan bahwa data posttest pada kedua kelompok sampel berdistribusi normal.

\section{Uji Homogenitas Data}

Pengujian homogenitas data digunakan untuk mengetahui apakah sampel yang digunakan dalam penelitian berasal dari populasi yang homogen atau tidak, artinya apakah sampel yang dipilih dapat mewakili seluruh populasi yang ada.

Untuk pengujian homogenitas digunakan uji kesamaan kedua varians yaitu uji F. Data masing-masing kelompok sampel dinyatakan memiliki varians yang homogen, apabila nilai $\mathrm{F}_{\text {hitung }}<\mathrm{F}_{\text {tabel }}$ pada taraf $\alpha=0,05$.

Tabel 5. Data Hasil Uji Homogenitas

\begin{tabular}{|c|c|c|c|}
\hline Data & $\mathbf{F}_{\text {hitung }}$ & $\mathbf{F}_{\text {tabel }}$ & Kesimpulan \\
\hline Pretest & 1,3330 & 1,7211 & Homogen \\
\hline Posttest & 1,2534 & 1,7211 & Homogen \\
\hline \multicolumn{5}{|c|}{ Dengan demikian, } & karena \\
$F_{\text {hitung }} \leq F_{\text {tabel }}$ maka disimpulkan bahwa
\end{tabular}

sampel pre test dan post test berasal dari data yang homogen.

\section{Uji Hipotesis}

Setelah diketahui kedua kelompok data kemampuan pemecahan masalah matematis siswa adalah berdistribusi normal dan mempunyai varians yang homogen, kemudian dilakukan pengujian hipotesis dengan menggunakan statistik uji-t. Dari pengujian hipotesis kemampuan pemecahan masalah matematis diperoleh $t_{\text {hitung }}>t_{\text {tabel }}$ yaitu $1,9044>1,6675$ maka $\mathrm{H}_{0}$ ditolak dan $\mathrm{H}_{\mathrm{a}}$ diterima. Secara ringkas hasil pengujian hipotesis kemampuan pemecahan masalah disajikan pada tabel 4.6 berikut:

\section{Tabel 6. Data Hasil Uji Hipotesis}

\begin{tabular}{|c|c|c|}
\hline $\mathbf{t}_{\text {hitung }}$ & $\mathbf{t}_{\text {tabel }}$ & Kesimpulan \\
\hline 1,9044 & 1,6675 & Terima $\mathrm{H}_{\mathrm{a}}$ \\
\hline
\end{tabular}

Dari hasil perhitungan pengujian hipotesis kemampuan pemecahan masalah , diperoleh $t_{\text {hitung }}=1,9044$ dengan meninjau harga $t_{\text {tabel }}$ pada $d k=75$ dan taraf signifikansi $\alpha=0,05$ diperoleh $t_{(0,95)(75)}=$ 1,6675 , ternyata $1,9044>1,6675$ maka $\mathrm{H}_{0}$ ditolak dan $\mathrm{H}_{\mathrm{a}}$ diterima. Dengan kata lain: Kemampuan pemecahan masalah matematis siswa yang belajar dengan menggunakan model pembelajaran MEAs lebih tinggi dari kemampuan pemecahan masalah matematis siswa yang belajar dengan menggunakan model pembelajaran PBL di SMP Negeri 38 Medan.

Hasil penelitian di atas relevan dengan penelitian oleh Dzulfikar (2012) diperoleh bahwa model pembelajaran Model Eliciting Activities dan Problem Based Learning efektif terhadap kemampuan pemecahan masalah, tetapi model pembelajaran Model Eliciting Activities lebih baik daripada Problem Based Learning. Selain itu, dari hasil penelitian Yu dan Chang (2009)

Novia Fadilah, Edy Surya. Perbandingan Kemampuan Pemecahan Masalah Matematis Siswa Menggunakan Model Eliciting Activities dan Problem Based Learning di Kelas VIII SMP Negeri 38 Medan, Inspiratif, Vol. 3, No. 1 April 2017. 
menunjukkan bahwa MEAs berguna untuk meningkatkan kemampuan pemecahan masalah peserta didik.

Sedangkan berdasarkan hasil penelitian Napitupulu (2013) menunjukkan bahwa tingkat kemampuan pemecahan masalah matematika siswa adalah tinggi dengan nilai rata-rata kelas 82,07 dimana jumlah siswa yang telah masuk kategori minimal sedang sebanyak 26 orang atau $89,66 \%$ dari seluruh siswa. Kemudian, berdasarkan hasil penelitian yang dilakukan oleh Sumartini (2016) dapat disimpulkan bahwa peningkatan kemampuan pemecahan masalah matematis siswa yang mendapat pembelajaran berbasis masalah lebih baik daripada siswa yang mendapat pembelajaran konvensional.

Surya dan Syahputra (2017) menemukan bahwa pembelajaran berbasis masalah dapat meningkatkan berpikir tingkat tinggi siswa dalam pembelajaran matematika. Amalia, Surya dan Syahputra (2017) juga menemukan bahwa pembelajaran lebih efektif dengan menggunakan problem based learning pada pemecahan masalah matematika pada siswa SMP.

Dari penjabaran diatas, dapat disimpulkan bahwa model pembelajaran MEAs dan PBL dapat meningkatkan kemampuan pemecahan masalah matematika siswa. Karena keduanya mampu meningkatkan kemampuan pemecahan masalah matematika siswa.

\section{KESIMPULAN}

Kemampuan pemecahan masalah matematis siswa yang belajar dengan menggunakan model pembelajaran MEAs lebih tinggi dari kemampuan pemecahan masalah matematis siswa yang belajar dengan menggunakan model pembelajaran PBL di SMP Negeri 38 Medan.

\section{DAFTAR PUSTAKA}

Amalia, E. Surya, E., Syahputra, E. (2017). The Effectiveness of Using Problem Based Learning (PBL) in Mathematics Problem Solving Ability For Junior High School Students. International Journal of Advanced Research and Innovative Ideas in Education. Vol.

Byod, W, dkk. 2014. Feeling Good about Teaching Mathematics: Addressing Anxiety amongst PreService Teachers. Scientific Research, Vol.5, P.207,208, (Online), (http://file.scirp.org/pdf/ CE2014031216264445.pdf, diakses 23 Februari 2017).

Chamberlin, S. A. dan Moon, S. M. 2008. How Does The Problem Based Learning Approach Compare to The Model-Eliciting Activity Approach in Mathematics?. International Journal for Mathematics Teaching and learning, (Online), (http://www.cimt.plymouth.ac.uk/j ournal/chamberlin .pdf, diakses 15 Januari 2017).

Delyana, H. 2015. Peningkatan Kemampuan Pemecahan Masalah Matematika Siswa Kelas VII Melalui Penerapan Pendekatan Open Ended. Lemma, Vol. 2, No. 1 , P. $26 . \quad$ (Online), (http://ejournal.stkip-pgrisumbar.ac.id/index.php /jurnallemma /article/view/523/318, diakses 8 April 2017).

Dzulfikar, dkk. 2012. Keefektifan Problem Based Learning Dan Model Eliciting Activities Terhadap Kemampuan Pemecahan Masalah. Jornal of Mathematics Education, Vol.1, No.1, P.1, ISSN.2252.6927, (Online),

Novia Fadilah, Edy Surya. Perbandingan Kemampuan Pemecahan Masalah Matematis Siswa Menggunakan Model Eliciting Activities dan Problem Based Learning di Kelas VIII SMP Negeri 38 Medan, Inspiratif, Vol. 3, No. 1 April 2017. 
(http://journal.unnes.ac.id/aju/inde x/ujme diakses 22 Februari 2017).

Hartono, Y. 2014. Matematika Strategi Pemecahan Masalah. Yogyakarta: Graha Ilmu.

Hudojo, H. 2005. Pengembangan Kurikulum dan Pembelajaran Matematika. Malang: Universitas Negeri Malang.

Latif, R.M. 2016. Problem-Solving Effects In Teaching And Learning Mathematics. International Journal of Innovation and Applied Studies, Vol. 18 No. 3 Nov. 2016, ISSN 2028-9324, P.909, (Online), (http://www.issrjournals.org/links/ papers.php?journal=ijias\&applicati on=pdf\&article=IJIAS-16-196-05, diakses 2 Maret 2017).

Lidinillah, A.B. 2008. Strategi Pembelajaran Pemecahan Masalah di Sekolah Dasar. Jurnal Pendidikan Dasar, No. 10, Oktober 2008, (Online), (http://file.upi.edu/DirektoriJURN AL/PENDIDIKAN DASAR/Nom or 10 Oktober 2008/Strategi Pe mbelajaran Pemecahan Masalah di_Sekolah_Dasar.pdf, diakses 23 Februari 2017).

Napitupulu, N.S. 2013. Upaya Meningkatkan Kemampuan Pemecahan Masalah Matematika Melalui Model Pembelajaran Problem Based Learning pada pokok bahasan Aritmatika Sosial di kelas VII SMP Hang Tuah-1 Belawan Tahun Pengajaran 2012/2013. Tesis. FMIPA UNIMED

Noor, A.J, dan Nurlaila. 2014. Kemampuan Pemecahan Masalah Matematika Siswa Dalam
Pembelajaran Matematika Menggunakan Model Cooperative Script. Jurnal Pendidikan Matematika. Vol.2, No.3, P.253, (Online), (http://id.portal garuda.org/article.php?article $=444$ 254\&val=9364, 12 Maret 2017).

Pehkonen. 2007. Problem Solving in Mathematics Education in Finland, [online] https://www.unige.ch/papers/peh kon.pdf (diakses pada tanggal 15 Februari 2017).

Permana, Y. 2015. Mengembangkan Kemampuan Pemahaman dan Komunikasi Matematis Siswa Sekolah Menengah Atas Melalui Model Eliciting Activities. (http://103.11.96.117/download/20 15/artikel/20150225-YP02STL01.pdf)

Sa'ad, T.U, Adamu, A, dan Sadiq, A.M. 2014. The Causes of Poor Performance in Mathematics among Public Senior Secondary School Students in Azare Metropolis of Bauchi State, Nigeria. Journal of Research \& Method in Education, Vol.4, No.6, e-ISSN. 2320-7388, P. 32, (Online), (https://pdfs. semanticscholar.org/fa47/dc53f2c7 f9ef8e4cd2ad1fb27dd50dfe4741.p df, diakses 23 Februari 2017).

Sanjaya, W. 2011. Strategi Pembelajaran Berorientasi Standar Proses Pendidikan. Bandung: Kencana Prenada Media.

Santillán, A.G, Escalera-Chávez,M.E dan Moreno-García, E, SantanaVillegas,.d.C. 2015. Factors that Explains Student Anxiety toward Mathematics. Eurasia Journal of

Novia Fadilah, Edy Surya. Perbandingan Kemampuan Pemecahan Masalah Matematis Siswa Menggunakan Model Eliciting Activities dan Problem Based Learning di Kelas VIII SMP Negeri 38 Medan, Inspiratif, Vol. 3, No. 1 April 2017. 
Mathematics, $\quad$ Science \& Technology Education, Vol.12, No.2, 361, ISSN: 1305-8223, P.361, (Online),

(http://www.iserjournals.com /journals /eurasia/ download /10.12973/eurasia.2016.1216a ,diakses 23 Februari 2017).

Sugiono. 2016. Metode Penelitian Kuantitatif, Kualitatif dan $R \& D$. Bandung: Alfabeta.

Sumartini, T.S. 2016. Peningkatan Kemampuan Pemecahan Masalah Matematis Siswa melalui Pembelajaran Berbasis Masalah. Jurnal Pendidikan Matematika STKIP Garut, Vol.8, No.3, April 2016, P. 11, ISSN 2086 4280, (Online), (jurnalmtk.stkipgarut.ac.id/data/edisi8/vol3/Tina.p $d f$, diakses 2 Maret 2017).

Surya, E. 2010. Visual Thinking dalam Memaksimalkan Pembelajaran Matematika Siswa Dapat Membangun Karakter Bangsa. Abmas UPI Bandung, Tahun 10 Nomor 10 Oktober 2010.

Surya, E. 2013. Peningkatan Kemampuan Representasi Visual Thinking pada Pemecahan Masalah Matematis dan Kemandirian Belajar Siswa SMP Melalui Pembelajaran Kontekstual. Disertasi. Universitas Pendidikan Indonesia.

Surya, E. and Syahputra, E. 2017. Improving High-Level Thinking Skills by Development of Learning PBL Approach on The Learning Mathematics for Senior High School Students. International Education Studies, 10(8), 12-20.
Konsep, Landasan, dan Implementasinya pada Kurikulum Tingkat Satuan Pendidikan (KTSP). Jakarta: Kencana Prenada Media Group.

Yu, S. dan Chang, C. 2009. What Did Taiwan Mathematics Teachers Think of Model-Eliciting Activities and Modeling?. International Conference on the Teaching of Mathematical Modeling and Applications, Vol.14, 148, 156, (Online), (http://120.107.180.177/1832/9802 198-2-04pa.pdf, diakses 20 Desember 2016).

Trianto. 2011. Mendesain Model Pembelajaran Inovatif-Progresif:

Novia Fadilah, Edy Surya. Perbandingan Kemampuan Pemecahan Masalah Matematis Siswa Menggunakan Model Eliciting Activities dan Problem Based Learning di Kelas VIII SMP Negeri 38 Medan, Inspiratif, Vol. 3, No. 1 April 2017. 